\title{
Phototransistor Based on Single TaON Nanobelt and Its Photoresponse from Ultraviolet to Near-infrared
}

\author{
TAO You-Rong, CHEN Jin-Qiang, WU Xing-Cai
}

(Key Laboratory of Mesoscopic Chemistry of MOE, State Key Laboratory of Coordination Chemistry, School of Chemistry and Chemical Engineering, Nanjing University, Nanjing 210023, China)

\begin{abstract}
TaON nanobelts (NBs) were controllably synthesized by $\mathrm{Ta}_{2} \mathrm{O}_{5}$ NBs template-conversion method. The typical NBs have cross-sections of $40 \mathrm{~nm} \times 200 \mathrm{~nm}-400 \mathrm{~nm} \times 5600 \mathrm{~nm}$, and lengths up to about $0.5 \mathrm{~cm}$. A field effect transistor (FET) based on single TaON NB was fabricated on $\mathrm{SiO}_{2} / \mathrm{Si}$ substrate. The electronic mobility and on-off ratio of the nanobelts are $9.53 \times 10^{-4} \mathrm{~cm}^{2} /(\mathrm{V} \cdot \mathrm{s})$ and 3.4, respectively. The FET shows good photoresponses from $254 \mathrm{~nm}$ to $850 \mathrm{~nm}$. Under irradiation of $405 \mathrm{~nm}$ light $\left(42 \mathrm{~mW} / \mathrm{cm}^{2}\right)$, the responsivity is $249 \mathrm{~mA} / \mathrm{W}$ at a bias of $5.0 \mathrm{~V}$, and the photoswitch current ratio is 11 . Therefore, the phototransistor shows a good photodetectivity, and TaON NBs may become good candidates for fabricating optoelectronic devices. Additionally, $\mathrm{Ta}_{2} \mathrm{O}_{5} @ \mathrm{TaON}$ composite NBs were also synthesized, and a FET based on the single NB was fabricated. Under irradiation of the same light, its photoresponse is weaker than TaON NB, but it is still a good optoelectronic material.
\end{abstract}

Key words: TaON nanobelt; template synthesis; field effect transistor; photodetector

One-dimensional (1D) nanostructures of semiconductors have extensively been applied as functional building blocks for electronic and optoelectronic devices such as field-effect-transistors (FETs) ${ }^{[1]}$, chemical sensors ${ }^{[2]}$, electronic field emitters ${ }^{[3-4]}$, photodetectors ${ }^{[5-7]}$, solar cells ${ }^{[8]}$, and supercapacitors ${ }^{[9]}$, because the reduced dimension brings about new physical-chemical properties, and 1D nanostructures are suitable for nanofabrication. Research shows that the high photoconductive gains of the low dimensional semiconductor photodetectors depend on both their high surface-area-to-volume ratios (SVRs) and the reduced dimension of the effective conductive channel, because the high SVRs can increase the number of surface trap states and prolong photocarrier lifetime, whereas the reduced dimensionality can confine the active area of the charge carrier, and shorten the transit time ${ }^{[10]}$. Photodetector from the ultraviolet (UV) to the infrared (IR) is critical for industrial and scientific applications such as images sensing, communications, environmental monitoring, remote control, day-andnight-time surveillance, and chemical/biological sensing $^{[11]}$. Although a few photodetectors based on nanostructures of metal oxides ${ }^{[12-13]}$, metal chalcogenides ${ }^{[14]}$, transition metal dichalcogenides (TMDs) ${ }^{[15-16]}$, and tran- sition metal trichalcogenides $(\mathrm{TMTs})^{[17-18]}$, are reported, it is still a challenge to develop low-cost, nontoxicity, high-detectivity and broadband response photodetector.

$\mathrm{TaON}$ is a semiconductor with a band gap of $2.4 \mathrm{eV}^{[19]}$. Its powders were once proposed as a nontoxic yellow pigment ${ }^{[20]}$. Recently, they have been used as visiblelight-driven photocatalyts to split water ${ }^{[21]}$ and oxidize methanol ${ }^{[22]}$. TaON powders could be prepared by calcination of $\mathrm{Ta}_{2} \mathrm{O}_{5}$ powders in the flowing $\mathrm{NH}_{3}$, for example, $\mathrm{Ta}_{2} \mathrm{O}_{5}$ could be totally converted to $\mathrm{TaON}$ in the flowing $\mathrm{NH}_{3}$ of $10 \mathrm{~mL} / \mathrm{min}$ at $800{ }^{\circ} \mathrm{C}$ for $10 \mathrm{~h}$, while totally converted to $\mathrm{Ta}_{3} \mathrm{~N}_{5}$ in a flowing $\mathrm{NH}_{3}$ of $1000 \mathrm{~mL} / \mathrm{min}$ at $800{ }^{\circ} \mathrm{C}$ for $10 \mathrm{~h}^{[23]}$. We once synthesized $\mathrm{Ta}_{3} \mathrm{~N}_{5}$ nanobelts (NBs) by direct aminolysis of $\mathrm{TaS}_{3} \mathrm{NBs}$ at high temperature, and discovered its good photosensitive properties from $250 \mathrm{~nm}$ to $630 \mathrm{~nm}^{[24]}$. In order to develop new photosensitive materials, here a $\mathrm{Ta}_{2} \mathrm{O}_{5} \mathrm{NB}$ template conversion method was employed to synthesize TaON NBs, and reaction time was reduced to $3 \mathrm{~h}$. Phototransistor based on single TaON NB shows good photoresponse from ultraviolet (UV) to near infrared (NIR), and have higher photoswitch current ratio (PCR) than $\mathrm{Ta}_{3} \mathrm{~N}_{5} \mathrm{NB}$ photodetector $^{[24]}$.

Received date: 2018-12-14; Modified date: 2019-03-12

Foundation item: National Natural Science Foundation of China (21673108); Open Foundations of State Key Laboratory of Coordination Chemistry (SKLCC1622)

Biography: TAO You-Rong (1964-), female, associate professor. E-mail: yrtao@nju.edu.cn

Corresponding author: WU Xing-Cai, Professor. E-mail: wuxingca@nju.edu.cn 


\section{Experiment}

\subsection{Preparation of TaON nanobelts}

Firstly, $\mathrm{TaS}_{3}$ NBs were prepared by chemical vapor transport method ${ }^{[25-26]}$. In typical process, $825 \mathrm{mg}$ of tantalum (Ta) foil $(99.9 \%, 0.2 \mathrm{~mm} \times 5 \mathrm{~mm} \times 45 \mathrm{~mm}), 146 \mathrm{mg}$ of sulfur (S) powders (99.99\%), and $15 \mathrm{mg}$ of iodine $\left(\mathrm{I}_{2}\right)$ powders $(99.8 \%)$ were sealed in a quartz ampoule in vacuum $\left(\phi 0.6 \mathrm{~cm} \times 12 \mathrm{~cm}, c a .10^{-2} \mathrm{~Pa}\right)$. The Ta foils were adjusted at the center of the ampoule and then the ampoule was placed at the center of a conventional horizontal furnace $(\phi 4 \mathrm{~cm} \times 32 \mathrm{~cm})$ with a temperature gradient of $c a .10{ }^{\circ} \mathrm{C} / \mathrm{cm}$ from center to end. Then the furnace was heated to $550{ }^{\circ} \mathrm{C}$ at a rate of $10{ }^{\circ} \mathrm{C} / \mathrm{min}$, kept at $550{ }^{\circ} \mathrm{C}$ for $8 \mathrm{~h}$, and cooled naturally to room temperature. $\mathrm{TaS}_{3}$ NBs on the Ta foils were extracted from the ampoule.

Secondly, $\mathrm{TaS}_{3}$ NBs were directly oxidized into $\mathrm{Ta}_{2} \mathrm{O}_{5}$ NBs at $650{ }^{\circ} \mathrm{C}$ for $2 \mathrm{~h}$ in air.

Finally, the $\mathrm{Ta}_{2} \mathrm{O}_{5}$ NBs were transferred into quartz coat, and placed in the center of the quartz tube of the horizontal furnace, then converted into green-yellow TaON NBs at $850{ }^{\circ} \mathrm{C}$ for $3 \mathrm{~h}$ in the flowing atmosphere of $\operatorname{Ar}(20 \mathrm{~mL} / \mathrm{min}) / \mathrm{NH}_{3}(80 \mathrm{~mL} / \mathrm{min})$ with a rising temperature rate of $10{ }^{\circ} \mathrm{C} / \mathrm{min}$.

\subsection{Characterization}

The products were characterized by X-ray diffractometer $(\mathrm{XRD})$ under monochromatized $\mathrm{Cu} \mathrm{K} \alpha$-radiation (Shimadzu XRD-6000), LEO-1530VP scanning electron microscope (SEM), JEOL-JEM-2010 high-resolution electron microscope (HRTEM) using imaging and selected area electron diffraction (SAED) with an energy dispersive X-ray spectrometer (EDX). The UV-Vis absorbance spectra of the products were recorded by UV3600 spectrophotometer (Shimadzu UV-3600).

\subsection{Device fabrication and measurements}

To fabricate field-effect-transistor (FET) of single NB, the TaON NBs were suspended in ethanol by brief sonication and then deposited on Si substrate with $300 \mathrm{~nm}$ thick thermal oxide layer serving as gate oxide. The standard photolithography technique followed by $\mathrm{Ti} / \mathrm{Au}$ $(10 \mathrm{~nm} / 100 \mathrm{~nm})$ metal evaporation and lift off were used to define the source and drain electrodes electrically contacting the NBs. The current-voltage $(I-V)$ and currenttime (I- $t$ ) characteristics of the photodetector were measured by SM-4 probe system and Keithley 236 source meter. The spectroscopic response ranging from $350 \mathrm{~nm}$ to $900 \mathrm{~nm}$ was measured using a $300 \mathrm{~W}$ Xe lamp (HSXUV300), and a multi-grating monochromator (71SW151) with ordered sorting filters. Small Lasers and ultraviolet lights were also used. Optical powers were measured with FZ-A, UV-340B, and UV-B radiometers. All measurements were carried out in air at room temperature.

\section{Results and discussion}

Fig. 1(a) shows the XRD pattern of as-prepared TaON NBs, which can be completely indexed as a monoclinic phase of TaON (JCPDS 71-0178). Fig. 1(b,c) display the low- and high-magnification SEM images of the NBs, respectively, revealing that the typical NBs have a rectangular section of about $40 \mathrm{~nm} \times 200 \mathrm{~nm}-400 \mathrm{~nm} \times 5600 \mathrm{~nm}$, and a length up to $0.5 \mathrm{~cm}$. Inset is the photography of NBs, showing faint yellow. Fig. 1(d) exhibits TEM image of single TaON NB, and inset shows the corresponding HRTEM image. The lattice fringe space of $0.31 \mathrm{~nm}$ corresponds to the (111) plane of TaON. Fast Fourier transform (FFT) pattern of the HRTEM image (inset on the upper right corner) further confirms it is monoclinic $\mathrm{TaON}$. To probe for synthetic condition of pure $\mathrm{TaON}$ $\mathrm{NBs}$, the same experiments were carried out at different temperatures. If $\mathrm{Ta}_{2} \mathrm{O}_{5} \mathrm{NBs}$ were calcined at $650{ }^{\circ} \mathrm{C}$ for $3 \mathrm{~h}$, the products were still $\mathrm{Ta}_{2} \mathrm{O}_{5}$. If $\mathrm{Ta}_{2} \mathrm{O}_{5} \mathrm{NBs}$ were calcined at $750{ }^{\circ} \mathrm{C}$ for $3 \mathrm{~h}$, only $\mathrm{Ta}_{2} \mathrm{O}_{5} @ \mathrm{TaON}$ composite NBs were synthesized. Fig. 2(a) is XRD pattern of the product at $750{ }^{\circ} \mathrm{C}$, indicating mixture of $\mathrm{Ta}_{2} \mathrm{O}_{5}$ (JCPDS 71-0639) and TaON (JCPDS 71-0178). Fig. 2(b) is SEM image of the composite NBs, revealing that the nanobelts are still a rectangular section of $40 \mathrm{~nm} \times 200 \mathrm{~nm}-400 \mathrm{~nm} \times$ $5600 \mathrm{~nm}$ and a length up to $0.5 \mathrm{~cm}$. Inset is a photography of the NBs with faint yellow. Fig. 2(c) displays TEM image of the composite NBs. TEM image of a single NB (Fig. 2(d)) further indicates a cladding structure. HRTEM image of square A is shown in Fig. 2(e), and both 0.31 and $0.28 \mathrm{~nm}$ of lattice fringe space correspond to ( 111$)$ and (111) plane of $\mathrm{TaON}$, respectively, and inset is its FFT pattern which can be indexed to TaON. Fig. 2(f) shows HRTEM image of square $\mathrm{B}$, and the lattice fringe space of $0.36 \mathrm{~nm}$ corresponds to (041) plane of $\mathrm{Ta}_{2} \mathrm{O}_{5}$, and the FFT pattern further confirms that the center part is $\mathrm{Ta}_{2} \mathrm{O}_{5}$. So the $\mathrm{NB}$ is a TaON-cladding $\mathrm{Ta}_{2} \mathrm{O}_{5} \mathrm{NB}$, namely, $\mathrm{Ta}_{2} \mathrm{O}_{5} @ \mathrm{TaON}$ NB. It is attributed to the conversion of $\mathrm{Ta}_{2} \mathrm{O}_{5}$ NBs from surface to center, however, $\mathrm{Ta}_{2} \mathrm{O}_{5}$ NBs cannot be all converted under the condition, so $\mathrm{Ta}_{2} \mathrm{O}_{5} @ \mathrm{TaON}$ NBs are formed.

A FET based on a single $\mathrm{TaON} \mathrm{NB}$ is depicted in Fig. 3(a). AFM image of the FET is represented in Fig. 3(b), and the height profile of the corresponding NB is shown in inset. The nanobelt between two electrodes is $1.42 \mu \mathrm{m}$ in width, $4.34 \mu \mathrm{m}$ in length, and $92 \mathrm{~nm}$ in thickness. Fig. 3(c) displays $I-V$ characteristics at gate voltage $\left(V_{\mathrm{g}}\right)$ 

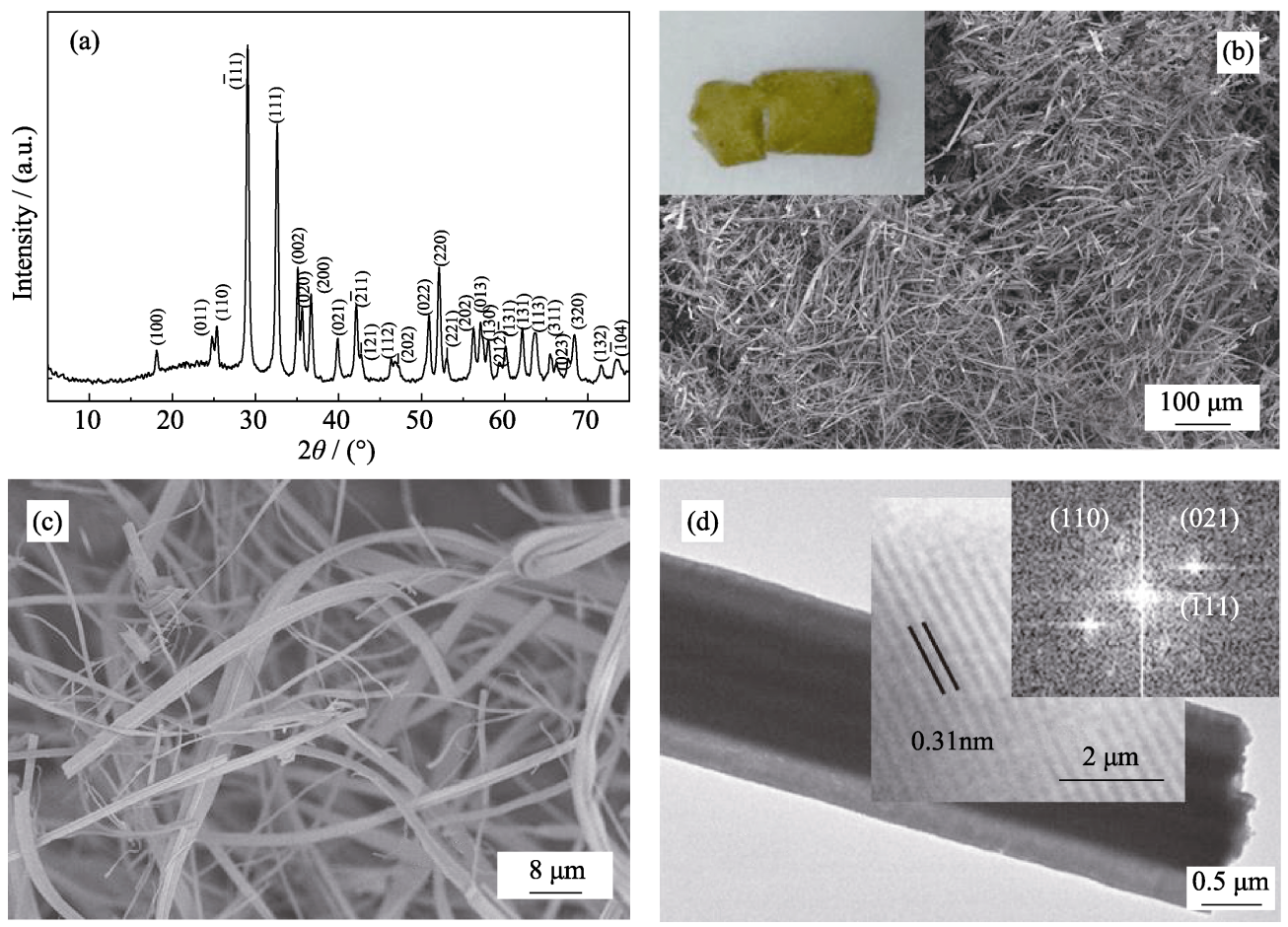

Fig. 1 (a) XRD pattern, (b) low-magnification SEM image (inset: light photograph), and (c) high-magnification SEM image of TaON nanobelts; (d) TEM image of a single TaON nanobelt with inset in the middle showing corresponding HRTEM image, and inset on the upper right corner showing FFT pattern of HRTEM image
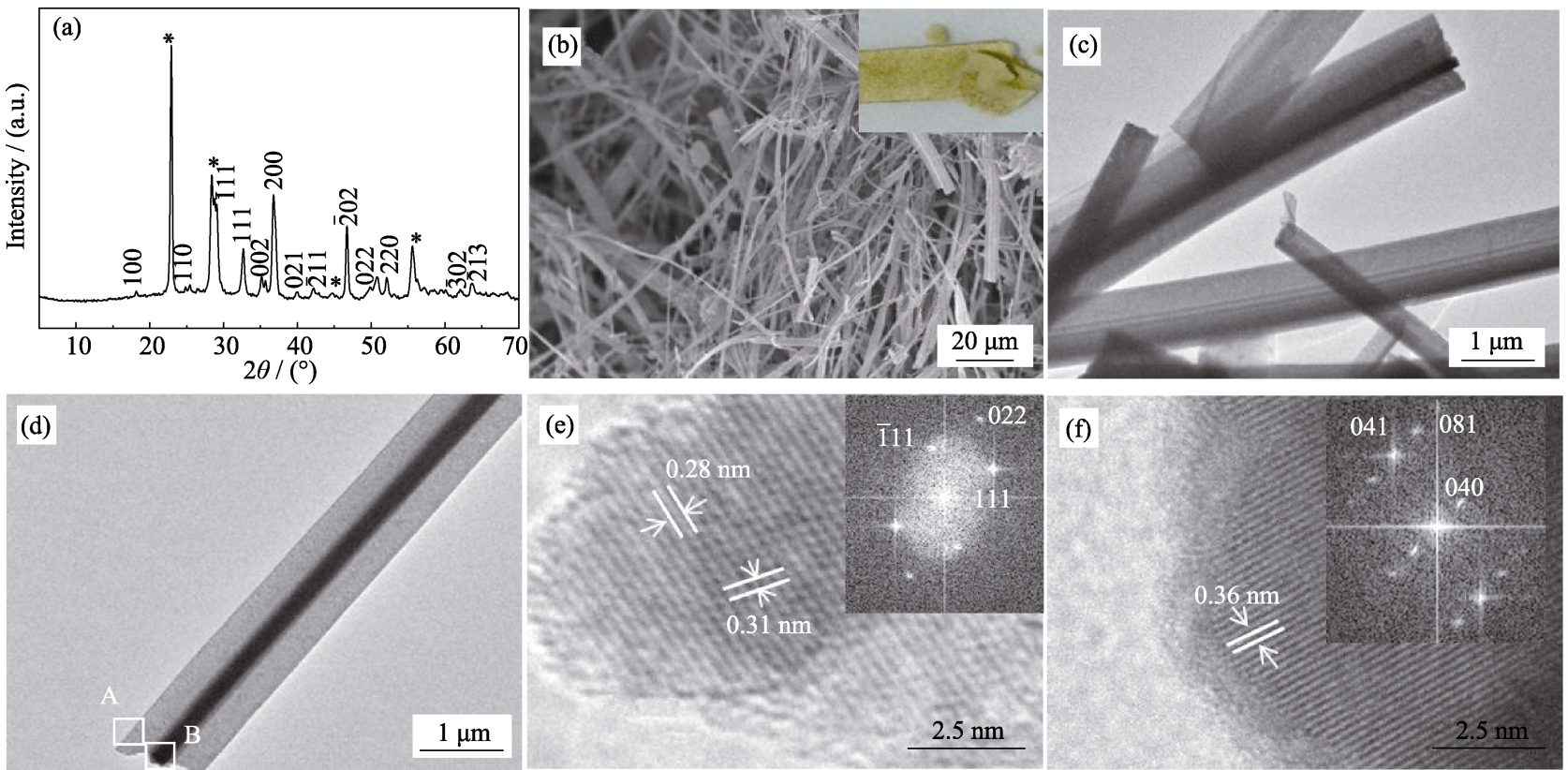

Fig. 2 (a) XRD pattern (a peak with star representing $\mathrm{Ta}_{2} \mathrm{O}_{5}$, and the rest peaks representing TaON), (b) low-magnification SEM image (inset: light photograph), and (c) TEM image of $\mathrm{Ta}_{2} \mathrm{O}_{5} @ \mathrm{TaON}$ composite nanobelts; (d) TEM image of a single Ta $\mathrm{O}_{5} @ \mathrm{TaON} \mathrm{Tanobelt}$

(e, f) HRTEM images of square A and B in (d), respectively with insets showing FFT patterns of corresponding HRTEM images

from $-20 \mathrm{~V}$ to $20 \mathrm{~V}$. It shows that the conductance of the NB increases monotonically as gate voltage increases, indicating that $\mathrm{TaON} \mathrm{NB}$ is an n-type semiconductor. The transfer characteristic of the FET at bias of $1 \mathrm{~V}$ is shown in Fig. 3(d). The $I_{\mathrm{ds}}-V_{\mathrm{g}}$ plot shows a threshold voltage $\left(V_{\text {th }}\right)$ of about $16 \mathrm{~V}$, and a linear-region trans- conductance $g_{\mathrm{m}}\left(\mathrm{d} I_{\mathrm{ds}} / \mathrm{d} V_{\mathrm{g}}\right)$ of $3.59 \times 10^{-12} \mathrm{~A} / \mathrm{V}$. An on-off ratio of 3.4 is measured. The electronic mobility $(\mu)$ can be calculated from the following equations: $\mu=$ $g_{\mathrm{m}} L /\left(C_{0} V_{\mathrm{ds}} W\right)$, where $W$ and $L$ are width and length of channel, respectively, and $C_{0}$ is the gate capacitance. Assuming a parallel plate capacitor model, $C_{0}=\varepsilon_{0} \varepsilon_{\mathrm{r}} / h$, 

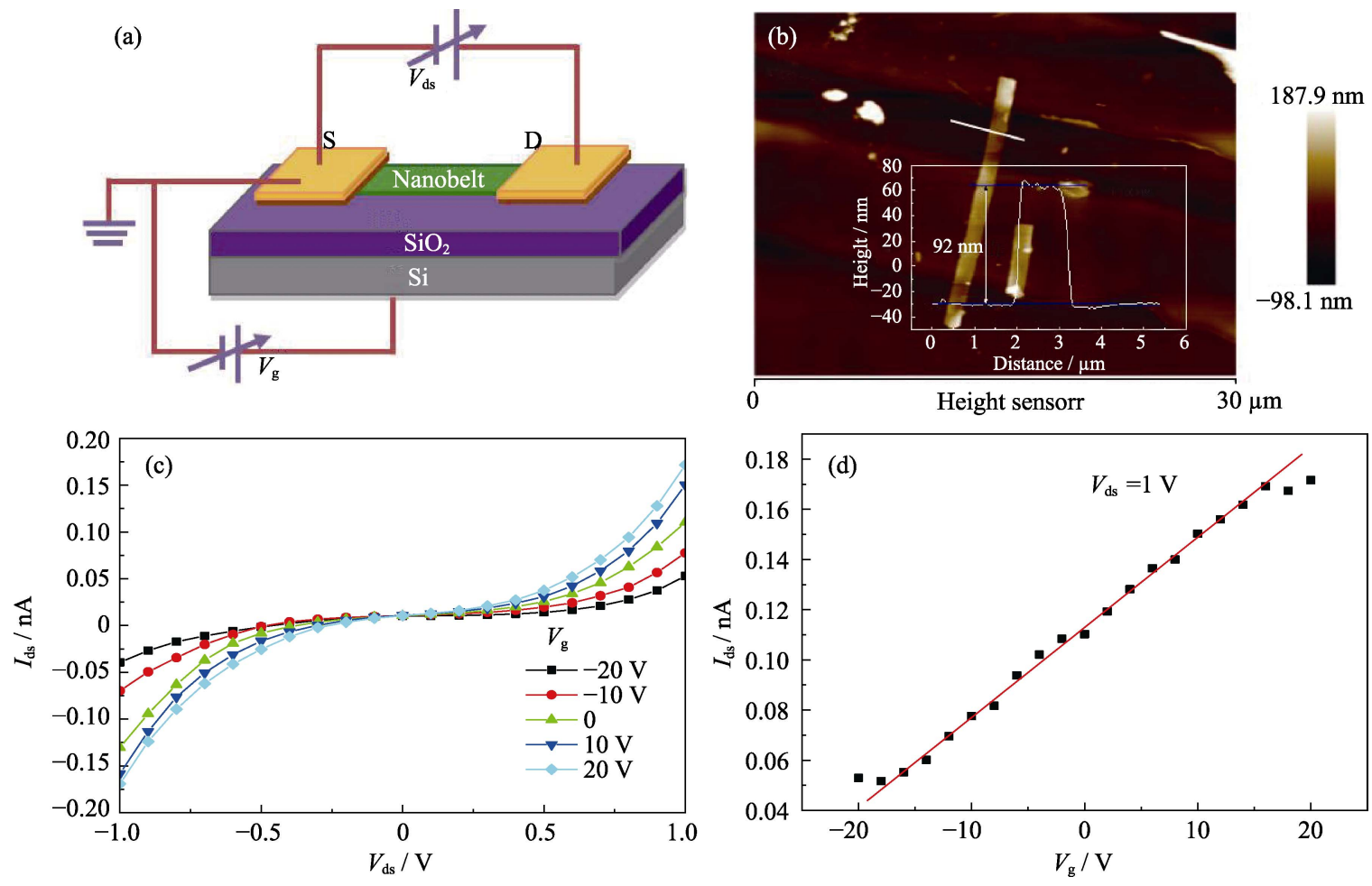

Fig. 3 (a) Scheme of FET based on a single TaON nanobelt; (b) Overlooked AFM image of the FET with inset showing size profile of the nanobelt; (c) $I_{\mathrm{ds}}-V_{\mathrm{ds}}$ plots at different $V_{\mathrm{g}}$; (d) $I_{\mathrm{ds}}-V_{\mathrm{g}}$ plot at $V_{\mathrm{ds}}=1 \mathrm{~V}$

where $\varepsilon$ is the dielectric constant $\left(\varepsilon_{\mathrm{r}}=3.9\right.$ for $\mathrm{SiO}_{2}, \varepsilon_{0}=$ $\left.8.854 \times 10^{-12} \mathrm{~F} / \mathrm{m}\right)$, and $h$ is the thickness $(300 \mathrm{~nm})$ of the gate oxide layer ${ }^{[28]}$. From above equation, the mobility is calculated to be $9.53 \times 10^{-4} \mathrm{~cm}^{2} /(\mathrm{V} \cdot \mathrm{s})$.

Fig. 4(a) shows a TaON NB FET which the channel is $0.71 \mu \mathrm{m}$ in width and $8.5 \mu \mathrm{m}$ in length, respectively. Fig. 4(b) is the $I-V$ curves of the TaON NB FET exposed to different wavelength light and under dark conditions, which exhibits good photoresponse from $254 \mathrm{~nm}$ to $850 \mathrm{~nm}$. Based on the data, responsivities to $254,365,405,532$, 650,780 and $850 \mathrm{~nm}$ at a bias of $5 \mathrm{~V}$ are 199, 237, 347, $53,45,28$, and $47 \mathrm{~mA} / \mathrm{W}$, respectively. The responsivity $\left(R_{\lambda}\right)$ and external quantum efficiency $(E Q E)$ are related to the number of electron-hole pairs excited by one absorbed photon, so high $R_{\lambda}$ and $E Q E$ correspond to the high sensitivity. $R_{\lambda}=\Delta I /(\mathrm{PS})$, and $E Q E=h c R_{\lambda} /(e \lambda)$, where $\Delta I$ is the difference between the illumination current and the dark current, $P$ is the light power intensity, $S$ is the irradiated area, and $\lambda$ is the light wavelength ${ }^{[24]}$. Fig. 4(c) shows the responsivities of the FET from $350 \mathrm{~nm}$ to $900 \mathrm{~nm}$, so the cut-off wavelength is about $900 \mathrm{~nm}$. As wavelength increases, the change trend is similar to UV-Vis absorption spectrum of the NBs (inset in Fig. 4(c)). Fig. 4(d) shows the $I-t$ curve of the FET under illumination of $405 \mathrm{~nm}$ light with a power of $42 \mathrm{~mW} / \mathrm{cm}^{2}$ at a bias of $5 \mathrm{~V}$ with a photoswitch period of $1 \mathrm{~s}$. Based on data of Fig. $4(\mathrm{~d}), R_{405 \mathrm{~nm}}=249 \mathrm{~mA} / \mathrm{W}, E Q E=7.2 \times 10^{5} \%$, and PCR is 11 . Here the responsivity is lower than that of Fig. 4(b), which can be attributed to the fact that current recovery needs more time under photoswitch. Fig. 4(e) displays the local-magnitude curve from $3.2 \mathrm{~s}$ to $5.6 \mathrm{~s}$ in Fig. 4(d), showing that the rise and recovery time of the photoswitch current are less than $0.2 \mathrm{~s}$, limited by instrument. Fig. 4(f) is the $I-t$ curve of the FET under illumination of $405 \mathrm{~nm}$ light with the same power and bias voltage with a photoswitch period of $50 \mathrm{~s}$, showing good stability of the photodetector.

Fig. 5(a) reveals micrograph of the FET based on a single $\mathrm{Ta}_{2} \mathrm{O}_{5} @ \mathrm{TaON}$ NB. The nanobelt between two electrodes is $1.4 \mu \mathrm{m}$ wide and $7.1 \mu \mathrm{m}$ long, respectively. Fig. 5(b) exhibts the responsivities of the FET to different wavelength light, showing the cut-off wavelength of about $900 \mathrm{~nm}$. The change trend is similar to UV-Vis absorption spectrum of the NBs (inset). Here the responsivity at $350 \mathrm{~nm}$ approaches that at $400 \mathrm{~nm}$, which may be attributed to the fact that photogenerating electrons of $\mathrm{Ta}_{2} \mathrm{O}_{5}$ join in photocurrents because $\mathrm{Ta}_{2} \mathrm{O}_{5}$ has only strong absorption at UV region. Fig. 5(c) shows the $I-V$ curves of the FET exposed to different-wavelength light. It also shows good photosensitive properties from $254 \mathrm{~nm}$ to $850 \mathrm{~nm}$. Fig. 5(d) shows the $I-t$ curve of the FET under illumination of $405 \mathrm{~nm}$ light $\left(42 \mathrm{~mW} / \mathrm{cm}^{2}\right)$ at a bias of $5 \mathrm{~V}$ with a photoswitch period of $50 \mathrm{~s}$. Here $R_{405} \mathrm{~nm}, E Q E$, and $P C R$ are $3.9 \mathrm{~mA} / \mathrm{W}, 1.1 \times 10^{4} \%$, and 2 , respectively, and rise and decay time of the photoswitch currents is less than $0.2 \mathrm{~s}$, limited by instrument. For comparison, a few 

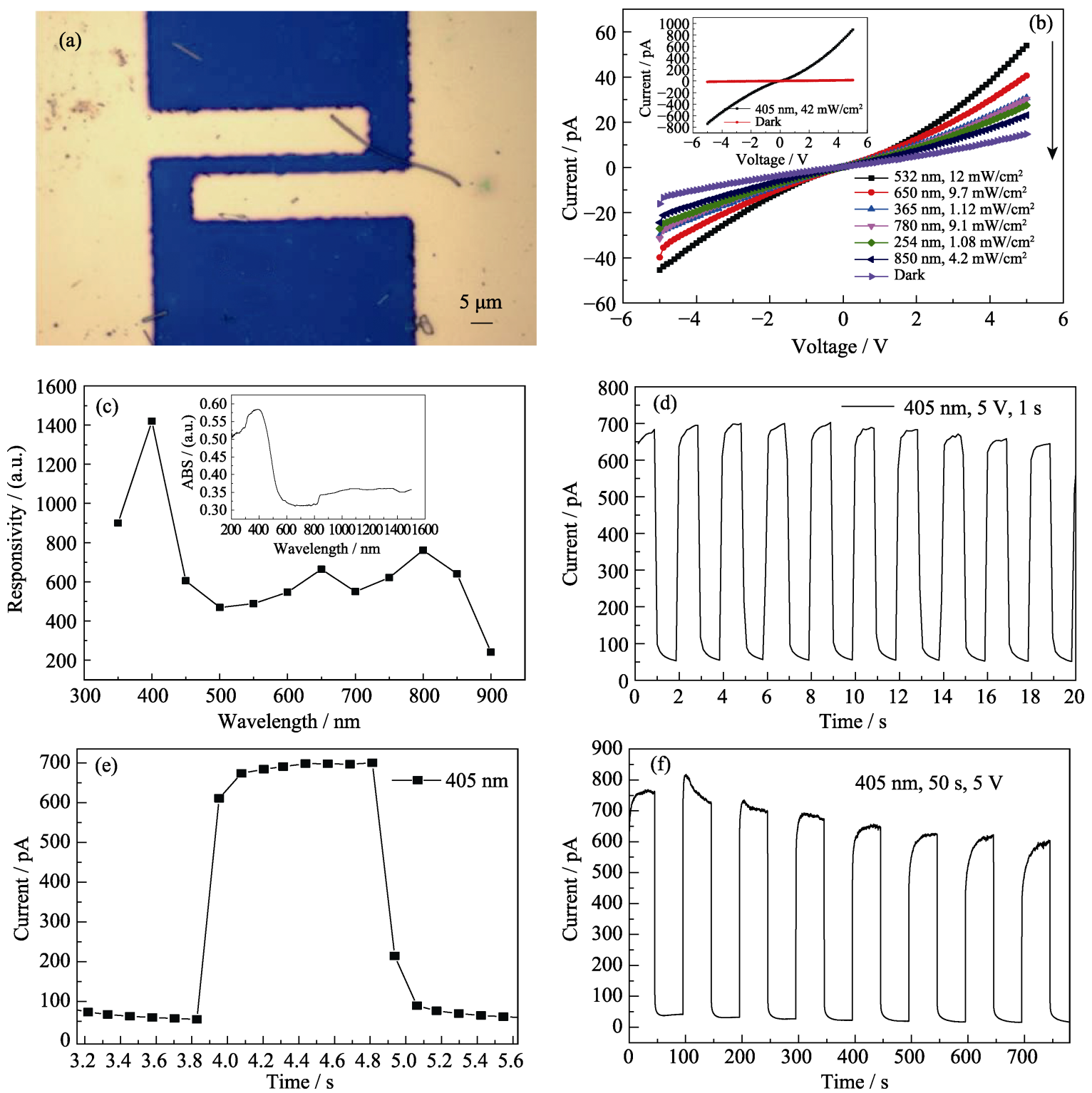

Fig. 4 (a) Photograph of a single TaON nanobelt FET, (b) $I$ - $V$ characteristics of the FET illuminated and unilluminated with different wavelength light, (c) responsivities of the FET to different wavelengths with inset showing UV-Vis absorption spectrum of TaON NBs,

(d, f) transient photoresponses of the FET illuminated by $405 \mathrm{~nm}\left(42 \mathrm{~mW} / \mathrm{cm}^{2}\right)$ light pulse chopped with a photoswitch period of 1 and $50 \mathrm{~s}$ at bias of $5 \mathrm{~V}$ and (e) local magnification of (d) from $3.2 \mathrm{~s}$ to $5.6 \mathrm{~s}$

results are included in Table 1. Based on Table 1, single TaON NB photodetector has higher responsivity than single-layer $\mathrm{MoS}_{2}$ and single GaS-nanobelt. Compared with $\mathrm{Ta}_{3} \mathrm{~N}_{5}$-NB photodetector, the TaON NB photodetector has lower responsivity, but higher $P C R$, so it is still good photodetector. Under the same illumination conditions, the single TaON NB photodetector higher $P C R$ and responsivity than the single $\mathrm{Ta}_{2} \mathrm{O}_{5} @$ TaON NB photodetector, so the former is superior to the latter. It may be attributed that $\mathrm{Ta}_{2} \mathrm{O}_{5} @ \mathrm{TaON} \mathrm{NB}$ contains less TaON than $\mathrm{TaON} N B$, and bandgap of $\mathrm{Ta}_{2} \mathrm{O}_{5}(3.9 \mathrm{eV})$ is greater than that of $\mathrm{TaON}(2.2 \mathrm{eV})$, so that photogenerating electrons of the composite NB reduce under illumination of the same light, so the photoresponse dwindles.

\section{Conclusion}

In the work, a $\mathrm{Ta}_{2} \mathrm{O}_{5} \mathrm{NB}$ template-synthesis route to TaON NB has been provided, which confirms that templateconversion is an efficient way to prepare nanowires (or NBs). $\mathrm{Ta}_{2} \mathrm{O}_{5} @ \mathrm{TaON}$ composite NBs can be also prepared by controlling conditions. The phototransistors based on both individual nanobelts show good responses from $254 \mathrm{~nm}$ to $850 \mathrm{~nm}$. Compared with $\mathrm{Ta}_{2} \mathrm{O}_{5} @ \mathrm{TaON}$ NB, TaON NB shows higher responsivity and $P C R$, but both may still become good candidates for optoelectronic devices, and can even be used in photocatalysis field. 
(a)
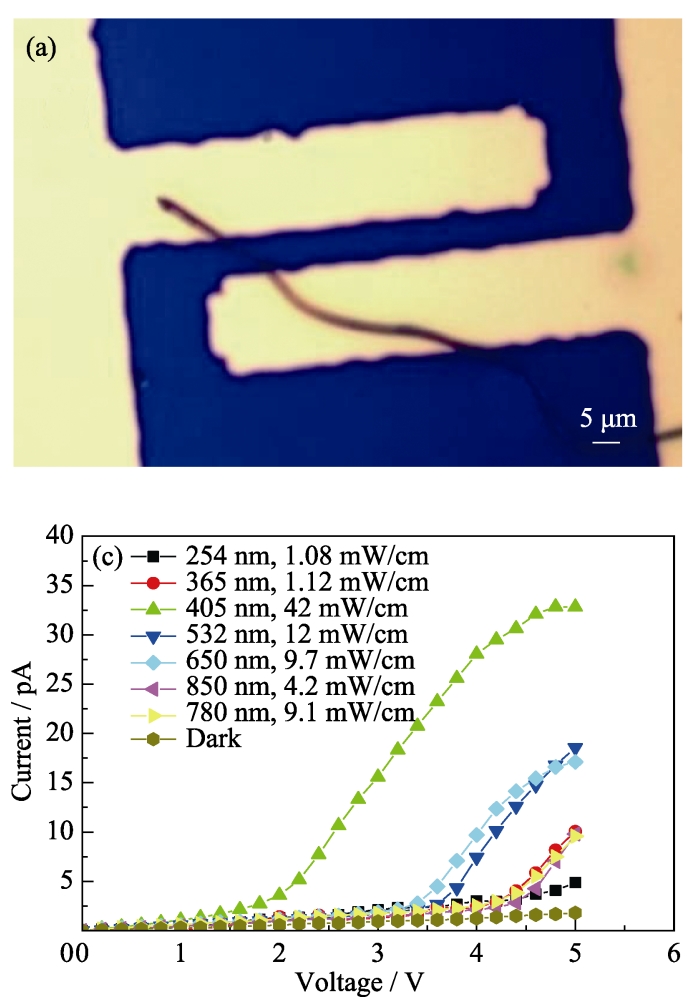
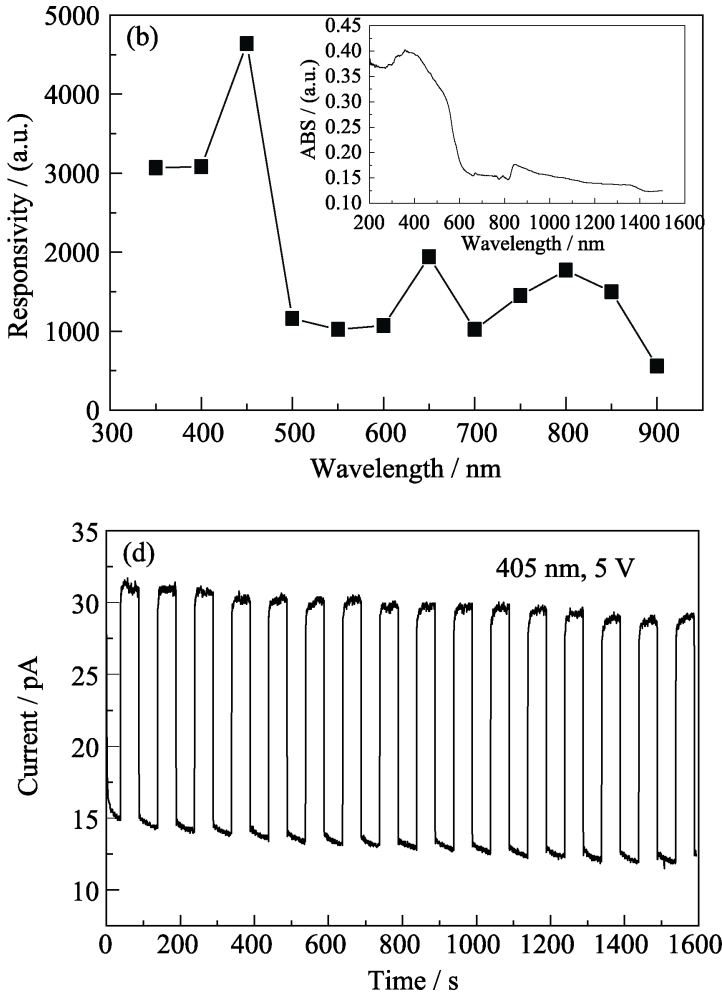

Fig. 5 (a) Photography of FET based on a single $\mathrm{Ta}_{2} \mathrm{O}_{5} @$ TaON nanobelt, (b) photoresponsivities of the FET to different wavelengths with inset showing UV-Vis absorption spectrum of Ta $\mathrm{O}_{5} @ \mathrm{TaON}$ NBs, (c) $I-V$ characteristics of the FET unilluminated illuminated with different wavelength light, and (d) transient responses of the FET illuminated with a $405 \mathrm{~nm}\left(42 \mathrm{~mW} / \mathrm{cm}^{2}\right)$

light pulse chopped with a photoswitch period of $50 \mathrm{~s}$ at a bias voltage of $5 \mathrm{~V}$

Table 1 Comparision of TaON NB photodetector with others reported

\begin{tabular}{|c|c|c|c|c|c|c|}
\hline Photodetector & Wavelength/Power & Bias voltage/V & $R_{\lambda} /\left(\mathrm{A} \cdot \mathrm{W}^{-1}\right)$ & $\begin{array}{l}\text { Photoswitch } \\
\text { current ratio }\end{array}$ & $\begin{array}{l}\text { Rise time/ } \\
\text { Decay time }\end{array}$ & Ref. \\
\hline CdTe NB & $400 \mathrm{~nm} / 637 \mu \mathrm{W} \cdot \mathrm{cm}^{-2}$ & 10 & 12 & 1.1 & $\sim 1.1 \mathrm{~s} / \sim 3.3 \mathrm{~s}$ & [27] \\
\hline Single-layer $\mathrm{MoS}_{2}$ & $550 \mathrm{~nm} / 80 \mu \mathrm{W}$ & 1 & $4.2 \times 10^{-4}$ & & $<0.05 \mathrm{~s}$ & {$[28]$} \\
\hline GaS NB & $490 \mathrm{~nm} / 0.5 \mathrm{~mW} \cdot \mathrm{cm}^{-2}$ & 2 & $2.3 \times 10^{-3}$ & & $<0.03 \mathrm{~s}$ & [29] \\
\hline $\mathrm{ZrS}_{3} \mathrm{NB}$ & $405 \mathrm{~nm} / 10.5 \mathrm{~mW} \cdot \mathrm{cm}^{-2}$ & 5 & 3.9 & 13 & $<0.4 \mathrm{~s}$ & [6] \\
\hline $\mathrm{Ta}_{3} \mathrm{~N}_{5} \mathrm{NB}$ & $450 \mathrm{~nm} / 2.8 \mathrm{~mW} \cdot \mathrm{cm}^{-2}$ & 2 & 99.6 & $\sim 1.5$ & $\sim 45 \mathrm{~ms} / 40 \mathrm{~ms}$ & {$[24]$} \\
\hline TaON NB & $405 \mathrm{~nm} / 42 \mathrm{~mW} \cdot \mathrm{cm}^{-2}$ & 5 & 0.249 & 11 & $<0.2 \mathrm{~s}$ & This work \\
\hline $\mathrm{Ta}_{2} \mathrm{O}_{5} @ \mathrm{TaON} \mathrm{NB}$ & $405 \mathrm{~nm} / 42 \mathrm{~mW} \cdot \mathrm{cm}^{-2}$ & 5 & $3.9 \times 10^{-3}$ & 2 & $<0.2 \mathrm{~s}$ & This work \\
\hline
\end{tabular}

\section{References:}

[1] GLUSCHKE J G, SEIDL J, BURKE A M, et al. Achieving short high-quality gate-all-around structures for horizontal nanowire fieldeffect transistors. Nanotechnology, 2019, 30(6): 064001-1-7.

[2] LIANG J R, ZHAO Y R, ZHU K L, et al. Synthesis and room temperature $\mathrm{NO}_{2}$ gas sensitivity of vanadium dioxide nanowire structures by chemical vapor deposition. The Solid Films, 2019, 669: 537-543.

[3] ZHANG Y L, WU X C, TAO Y R, et al. Fabrication and field-emission performance of zirconium disulfide nanobelt arrays. Chemical Communications, 2008(23): 2683-2685.

[4] WU X C, HONG J M, TAO Y R, et al. Controlled growth and field-emission properties of $\mathrm{NbSe}_{2}$ micro/nanostructured films. Journal of Nanoscience and Nanotechnoloy, 2010, 10(10): 6465-6472.
[5] TAO Y R, WU X C, XIONG W W. Flexible visible-light photodetectors with broad photoresponse based on $\mathrm{ZrS}_{3}$ nanobelt films. Small, 2014, 10(23): 4905-4911.

[6] TAO Y R, WU J J, WU X C. Enhanced ultraviolet-visible light responses of phototransistors based on single and a few $\mathrm{ZrS}_{3}$ nanobelts. Nanoscale, 2015, 7(34): 14292-14298.

[7] TIAN W, ZHANG C, ZHAI T Y, et al. Flexible ultraviolet photodetectors with broad photoresponse based on branched $\mathrm{ZnS}-\mathrm{ZnO}$ heterostructure nanofilms. Advanced Materials, 2014, 26(19): 3088-3093.

[8] VETTORI M, PIAZZA V, CATTONI A, et al. Growth optimization and characterization of regular arrays of GaAs/AlGaAs core/shell nanowires for tandem solar cells on silicon. Nanotechnology, 2019, 30(8): 08400-1-15.

[9] GU S S, LOU Z, MA X D, et al. $\mathrm{CuCo}_{2} \mathrm{O}_{4}$ nanowires grown on a $\mathrm{Ni}$ wire for high-performance flexible fiber supercapacitors. ChemElectroChem, 2015, 2(7): 1042-1047. 
[10] PENG L, HU L F, FANG X S. Low-dimensional nanostructure ultraviolet photodetectors. Advanced Materials, 2013, 25(37): 5321-5328.

[11] GONG X, TONG M H, XIA Y J, et al. High-detectivity polymer photodetectors with spectral response from $300 \mathrm{~nm}$ to $1450 \mathrm{~nm}$. Science, 2009, 325(5948): 1665-1667.

[12] BORUAH B D, MUKHERJEE A, MISRA A. Sandwiched assembly of $\mathrm{ZnO}$ nanowires between graphene layers for a self-powered and fast responsive ultraviolet photodetector. Nanotechnology, 2016, 27(9): 095206-1-11.

[13] ZHAO Y M, FENG S L, JIANG H T, et al. Catalyst-free growth of a $\mathrm{Zn}_{2} \mathrm{GeO}_{4}$ nanowire network for high-performance transfer-free solar-blind deep UV detection. Physica E-Low-Dimensional Systems Nanostructures, 2019, 107: 1-4.

[14] GERTMAN R, HARUSH A, VISOLY-FISHER I. Nanostructured photocathodes for infrared photodetectors and photovoltaics. Journal of Physical Chemistry C, 2015, 119(4): 1683-1689.

[15] WU J J, TAO Y R, WU Y, et al. Ultrathin $\mathrm{SnS}_{2}$ nanosheets of ultrasonic synthesis and their photoresponses from ultraviolet to near-infrared. Sensor and Actuators B-Chemical, 2016, 231: 211- 217.

[16] HAFEEZ M, GAN L, LI H Q, et al. Large-area bilayer $\operatorname{ReS}_{2}$ film/multilayer $\mathrm{ReS}_{2}$ flakes synthesized by chemical vapor deposition for high performance photodetectors. Advanced Functional Materials, 2016, 26(25): 4551-4560.

[17] XIONG W W, CHEN J Q, WU X C, et al. Visible light detectors based on individual $\mathrm{ZrSe}_{3}$ and $\mathrm{HfSe}_{3}$ nanobelts. Journal of Materials Chemistry C, 2015, 3(9): 1929-1934.

[18] TAO Y R, CHENJ Q, WU J J, et al. Flexible ultraviolet-visible photodetector based on $\mathrm{HfS}_{3}$ nanobelt film. Journal of Alloys and Compounds, 2016, 658: 6-11.

[19] CHUN W J, ISHIKAWA A, FUJISAWA H, et al. Conduction and valence band positions of $\mathrm{Ta}_{2} \mathrm{O}_{5}, \mathrm{TaON}$, and $\mathrm{Ta}_{3} \mathrm{~N}_{5}$ by UPS and electrochemical methods. Journal of Physical Chemistry B, 2003, 107(8): 1798-1803.

[20] BERTAUX S, REYNDERS P, HEINTZ J M, et al. New (oxy) nitride pearlescent pigments. Materials Science Engineering B, 2005, 121 (1/2): 137-144.

[21] CHEN S S, QI Y, HISATOMI T, et al. Efficient visible-light-driven $\mathrm{Z}$-scheme overall water splitting using a $\mathrm{MgTa}_{2} \mathrm{O}_{6-x} \mathrm{~N}_{y} / \mathrm{TaON}$ heterostructure photocatalyst for $\mathrm{H}_{2}$ evolution. Angewandte Chemie International Edition, 2015, 54 (29): 8498-8501.

[22] ITO S, THAMPI K P, COMTE P, et al. Highly active mesomicroporous $\mathrm{TaON}$ photocatalyst driven by visible light. Chemical Communications, 2005(2): 268-270.

[23] NAKAMURA R, TANAKA T, NAKATO Y. Oxygen photoevolution on a tantalum oxynitride photocatalyst under visible-light irradiation: how does water photooxidation proceed on a metaloxynitride surface? Journal of Physical Chemistry B, 2005, 109(18): 8920-8927.

[24] WU X C, TAO Y R, LI L, et al. Centimeter-long $\mathrm{Ta}_{3} \mathrm{~N}_{5}$ nanobelts: synthesis, electrical transport, and photoconductive properties. Nanotechnology, 2013, 24 (17): 175701.

[25] WU X C, TAO Y R, GAO Q X, et al. Superconducting TaS $\mathrm{T}_{2-x} \mathrm{I}_{y}$ hierarchical nanostructures. Chemical Communications, 2009(28): 4290-4292.

[26] WU X C, TAO Y R, GAO Q X. Fabrication of $\mathrm{TaS}_{2}$ nanobelt arrays and their enhanced field-emission. Chemical Communications, 2009(40): 6008-6010.

[27] XIE X, KWOK S Y, LU Z Z, et al. Visible-NIR photodetectors based on CdTe nanoribbons. Nanoscale, 2012, 4(9): 2914-2919.

[28] YIN Z Y, LI H, LI H, et al. Single-layer $\mathrm{MoS}_{2}$ phototransistors. ACS Nano, 2012, 6(1): 74-80.

[29] HU P A, WANG L F, YOON M, et al. Highly responsive ultrathin $\mathrm{GaS}$ nanosheet photodetectors on rigid and flexible substrates. Nano Letters, 2013, 13(4): 1649-1654.

\title{
基于单根 TaON 纳米带的光晶体管与紫外到近红外响应
}

\author{
陶友荣，陈晋强，吴兴才 \\ (南京大学 化学化工学院, 教育部介观材料重点实验室, 配位化学国家重点实验室, 南京 210023)
}

摘 要: 用 $\mathrm{Ta}_{2} \mathrm{O}_{5}$ 纳米带模板转化法控制合成 $\mathrm{TaON}$ 纳米带, 典型的纳米带长约 $0.5 \mathrm{~cm}$, 横截面积 $40 \mathrm{~nm} \times 200 \mathrm{~nm} \sim$ $400 \mathrm{~nm} \times 5600 \mathrm{~nm}$ 。在 $\mathrm{SiO}_{2} / \mathrm{Si}$ 基片上加工出 $\mathrm{TaON}$ 单根纳米带的场效应晶体管; 该晶体管的电子迁移率和开关比分 别为 $9.53 \times 10^{-4} \mathrm{~cm}^{2} /(\mathrm{V} \cdot \mathrm{s})$ 和 3.4, 在 254 850 nm 范围内显示良好的光响应。在 $405 \mathrm{~nm}\left(42 \mathrm{~mW} / \mathrm{cm}^{2}\right)$ 的光照下, 外加 $5.0 \mathrm{~V}$ 的偏压时, 光响应为 $249 \mathrm{~mA} / \mathrm{W}$, 光开关比为 11 。因此, 该器件具有良好的光探测性, $\mathrm{TaON}$ 纳米带可作为光电子器件 的候选材料。另外, 实验还控制合成出 $\mathrm{Ta}_{2} \mathrm{O}_{5} @ \mathrm{TaON}$ 纳米带, 并加工成单根纳米带的场效应晶体管, 虽然相同光照条 件下的光响应弱于 $\mathrm{TaON}$ 纳米带, 但仍算是一种好的光电材料。

关 键 词: $\mathrm{TaON}$ 纳米带; 模板合成; 场效应晶体管; 光探测器

中图分类号: TQ174 文献标识码: A 